\title{
HIDDEN CULTURE IN DIFFERENT CONCEPTUAL MEANING OF INDONESIAN POPULAR FOOD AMONG JAVANESE PEOPLE IN JAVA ISLAND
}

\author{
Irma Nirmala \\ ierma_ir@yahoo.com
}

\begin{abstract}
Different conceptual meaning of Indonesian popular food can be happened among Javanese people in Java Island due to having distinctive food perception. When people in East Java order the popular food (Bakso or Tempe tepung) at food stall, café, or restaurant in Central Java, they will probably get food which is not same as their perception or experience like in East Java. It is caused people in Central Java have own conceptual meaning of food in spite of having same name. This study finds two possibilities of conceptual meaning. They are having same name but different conceptual meaning and vice versa. Obviously its conceptual meaning represents their culture, such as the taste of food, the use of food in special event, type of food, and the eaters. Even though the meal itself has become a part of culture, because it is belong to outcome from the local community. It has gone that way, because people in group of community or area repeat cooking activity many times. It becomes habit; and it is continued by next generation.
\end{abstract} Key words: Culture and Conceptual Meaning

\section{INTRODUCTION}

Humans are social beings. They go beyond other creatures. They have ideas and senses to interact, communicate, and socialize with others. Pateda (1990) has acknowledgement that language has functions to convey our feeling to others (happy, sad, giving statement, question, or hope), to find out what happening in the past and at other place, to record what is happening and what will be happened, to pass the culture down to the next generation. Here, humans use the language for communication. Language is a communication tool. It can be verbal language (spoken and written language) or nonverbal language (body language, picture, symbol, et cetera).

Language is dynamic. It does not wonder language always developed and changed. There is possibility new words emerge anytime. Nonetheless, it does not mean the old words cease to exist, as long as the language users still apply it in the communication. People create a new word for giving a name to something or somebody. The purposes are to distinguish it with other and to announce to public that it is someone's possession or creation. It indicates that a word has meanings, and so do the name of food. The example is Lemper.

Lemper is a traditional snack in Indonesia. It is tasteful. It is made of steamed glutinous rice with meat floss, chopped beef, shaded chicken or fish stuffing and wrapped in banana leaf. Nowadays plastic wrapping replaces the banana leaf. Javanese people usually make it for special event like in wedding. Old people said that snacks are made from glutinous rice is a must in wedding to make the relationship between the bride and the groom become sticky like glutinous rice. Besides, lemper can be just snack which is eaten before eating the main 
course. Years by years, people also can serve it as snack for meeting event or traditional event. People can find it easily. They even can buy and eat it every day if they want to. Lemper can be bought in traditional market or in traditional snack store. The food concept of lemper and the ingredient are same everywhere. People just have diversity in serving. Several people wrap it in banana leaf or plastic wrapping, and others fry it directly without wrapping as new creation.

That explanation hereby declares Javanese people have same conceptual meaning about the food "lemper" indirectly. It is proved they have same idea about it like the above definition wherever they are. Besides, the Javanese people's belief about the existence of glutinous snack in wedding shows the culture. However, it does not have any correlation between lemper and someone's relationship. That snack becomes traditional food in Java wedding event, groom's accompaniment or other events up to now. It has become tradition for Javanese people from the ancestors. The young generations keep preserving the tradition without asking why, knowing the history background or trusting the belief or not. They just do to continue the tradition. It signifies that the tradition is part of culture which hides behind the conceptual meaning of food "lemper".

Study about relationship between language and culture is called ethnolinguistics. "ethnolinguistics (n.) is a branch of linguistics which studies language in relation to the investigation of ethnic types and behavior." (Crystal, 2008, p. 174). The language includes all language aspects not only about lexical word, word in order, and the meaning of word but also about language and society, discourse analysis, and the society itself. Language users will get correct interpretation about the culture by understanding all those language aspects, because they are related to. The culture is related to how people's behavior, what dance and music they play, what kinds of art they have (literature, painting), what food, snack, and cake they consume, and what belief they have. Discussing about language and culture are quite interesting.

Indonesia has various cultures. It is a rich country in diversity of music, dance, language, ethnic group, snack, cuisine included. Indonesia is a maritime country. It has many big and small islands, such as Kalimantan Island, Sumatera Island, Sulawesi Island, Bali Island, Java Island, et cetera. Each Island has several regions. In fact each area has own traditional food, such as pempek (Indonesian traditional food) in Palembang-South Sumatra, gudeg in Yogyakarta-Central Java, rujak cingur in Surabaya-East Java, and many more. Those foods are only in the original place. If there is gudeg in Surabaya, it means that it is a copy of gudeg from Yogyakarta. It can be one of the branch restaurants of gudeg from Yogyakarta or people who are from Yogyakarta open gudeg restaurant in Surabaya or Surabaya people ask the gudeg receipt from Yogyakarta citizen to open gudeg restaurant. There are other possibilities as well.

When Yogyakarta citizens order gudeg at restaurant or café in Surabaya, they will get gudeg according to what gudeg concept on their mind. They will get of young jackfruit cooked in coconut milk (It takes hours to make the dish). It is served with white rice, chicken, egg, tofu, tempeh, and krecek sambal. Surabaya citizens make the dish with same concept as Yogyakarta citizens do. It means the Surabaya citizens have same cognition with Yogyakarta citizens about gudeg. It does not matter if the gudeg is not totally the same as in Yogyakarta. The different is just the toping variant and the taste automatically. At least, the Yogyakarta people get correct 
concept of the dish based on the menu which they order at Surabaya café or restaurant. They are not too disappointed. The taste depends on each person. Everyone has their own taste to food.

Then, the researcher is curious whether there is Indonesian meal which causes Indonesian people have different conceptual meaning. What meals they are and what the reasons they are different. However, this study will not explore about the history background and the etymology of the word. The scope of the study is to analyze what different conceptual meaning of Indonesian popular food among Javanese people in Java Island and to mention what foods they are. By analyzing the diversity of conceptual meaning of food, the researcher will know the culture which is behind the food implicitly.

The researcher narrows the research only in Java Island-Indonesia. It is caused Java Island has many populations. There are many traditional food there likewise. People are more creative to invent new menu. It makes the food in Java Island is more diverse. This study picks and chooses several Indonesian popular food which is easy to be found everywhere (in restaurant, café, food stall, rest area, et cetera). The popular food can be from the traditional food, but the popularity is rising in society.

The data is collected through interviewing random thirty people. The most important is the interviewees must be citizen in one of cities in Java Island and they have ever eaten the other famous food in other cities in Java Island or not. Those thirty respondents are the representative for this study. The objections of this study are to know what popular Indonesian food that has different conceptual meaning among Javanese people in Java Island; and to know what the hidden culture is behind it.

\section{ARBITRARINESS}

Language is arbitrary. There is no logic explanation or even particular reason why a language refers to an object and how it is possible. "Arbitrariness: a property of language describing the fact that there is no natural connection between a linguistic form and its meaning". (Yule, 2006, p. 237). The example is kuda in Indonesian language. The word kuda refers to an animal whose has four legs and tail. The animal usually carries things or pulls vehicles. People can ride on it too. The word Kuda does not have logic meaning or correlation with the animal. Language users also cannot judge that kuda is a correct name to represent the four-footed animal. They have called it since their ancestor era. A long time ago, the ancestors agreed to call that animal kuda. Then it is followed by the next generation without rejecting up to now.

In addition, there is language that has less arbitrariness. It is onomatopoeia; the example is moo, meow, boom, et cetera. "onomatopoeia/onomatopoeic refers to words whose pronunciations suggest their meaning, e.g., meow, buzz." (Fromkin, 2011, p. 587). Onomatopoeia has closely connection with the object. It has the meaning. It comes from sound of the object itself. When language users listen, read, or pronoun a word (e.g. moo), their mind refer to cow automatically and directly. It is caused moo looks like a sound that emit from cow. It is a copy the sound of cow.

\section{WORD, MEANING, AND CULTURE}

Everything in this universe has meaning for the existence, despite only a movement or a word. Something related to words are called lexical. Each lexical word has meaning; and the study of meaning is called as semantics. "Lexical semantics is concerned with the 
overall meaning of words." (Meyer, 2009, p. 149). Knowing the lexical semantics is useful for language learner especially. When a word is ordered in a good sentence, learners must connect the whole words in a sentence to get correct understanding. So, the learner must choose the correct definition each word to be able to comprehend the sentence. As we know there is a word which has not only more than two or three meanings but also two functions or more (it can be as noun, verb, adverb, or adjective). Learners usually find this case in dictionary.

Leech (1981) has acknowledged that there are 7 types of meaning. They are conceptual meaning, connotative meaning, social meaning, affective meaning, reflected meaning, collocative meaning, and thematic meaning. Words have definition, but not all definitions are in dictionary. Sometimes there are words which the meanings are out of the terms. Dictionary even cannot give the explanation. The example is the word "woman". It means a human, the specific term is an adult female; and the dictionary will say so. It is the denotative meaning. That is logic as well. It is called as conceptual meaning or sense. That is the correct use of the word woman. However the term woman can have contrast definition from previous explanation, if it is used in other purpose. It does not mean the term woman who has a womb and breasts in physically. It is someone who has attitude like or refers to woman psychologically and socially. The psychology and social of woman is frail, prone to tears, coward, emotional, talk active, irrational. Those attributes are inherent in woman. It is the reality which is from the real world experience. It is called connotative meaning when the word refers to something which has distinctive meaning about conceptual meaning.

Each region and each ethnic group have own way to use language. It depends on the language users in the society. The dialect and the accent are not same to one another. They imply social meaning, because the language usage based on the social circumstance. Language has power. It can influence somebody. It reflects what the speakers' feeling; and the result affects to the listener's attitude or perception. It emerges clearly when seller persuades buyer to buy the merchandise although the buyer do not really need. If the buyer buys the product, it describes that buyer has been effected with the seller words explicitly. It is the name of effective meaning which conveys someone to move or do something else from the activity.

In addition, by using proper language, speaker has ability to make the listeners to be happy, sad, surprise, and other emotions that look on the listeners' face. Listeners listen something funny; automatically laugh comes out from their face. The laugh is a sense of words forms response or another sense that is belongs to reflective meaning. One more time, society or environment takes a role in word meaning. Collocative meaning consists of group of words acquire meanings which tend to occur in society or environment. The example is the word pretty. It is combined with the word girl, boy, woman, village, garden, et cetera. As we know that the lexical word pretty means pleasant to look at. It is used for girl, woman, or something which connected to them, but it does not matter to be used for boy or village. It is caused it fits to be used in place where the language users live. The environment seems agree and there is no opposition.

Social meaning, affective meaning, reflected meaning, and collocative meaning are common in connotative meaning than conceptual meaning. They are united under the heading of associative meaning. Conceptual meaning concerns about linguistics (phonology, syntax, and semantics). It 
comes from the word, form of words, sentence, and the pronunciation; whereas, the associative meaning concerns about pragmatics and society. It means it has a meaning of real life. So, it will vary with individual's experience each human being. The last type of meaning is thematic meaning. It is related to how the language users arrange the message in order, focus, and emphasis. By using correct grammar and knowing where the stress of the message, the language users will be able to understand each other easily and to minimize the misunderstanding in the communication.

In addition, language keeps moving on in society continuously. The language users keep creating new word to name something new, such as new product, new person, new meal, new drink, new place et cetera. The function is to distinguish between existed thing and new thing. It is the easiest way to refer something new. Its name can be related to the meaning, the function, the inventor's name, or the appearance of the thing itself. Therefore, it signifies that there must be a story or a culture behind a name. The study of language and culture is anthropological linguistics.

Anthropological linguistics is a branch of linguistics which studies the role of language in relation to human cultural patterns and beliefs, as investigated using the theories and method of anthropology. For example, it studies the way in which linguistic features vary in order to identify a member of a speech community with a social, religious, occupational or kinship group. Any social situation can be explored from an anthropological point of view, such as everyday interaction, ritual behavior, political discourse, verbal art and educational practice. The term overlaps to some degree which ethnolinguistics and sociolinguistics, reflecting the overlapping interests of the correlative disciplines involved-anthropology, ethnology and sociology. When the research takes place primarily within an anthropological paradigm, the subject is known as linguistic anthropology, and the practitioners as linguistic anthropologists. (Crystal, 2008, p. 53)

Language and culture cannot be separated in society. People in society use language for communication, and they can create a culture in a small group or even in big community which has possibility to become a custom. They are overlapping in society. Language can be culture output or vice versa. It depends on where people view it

\section{DISCUSSION}

Java Island is one of big islands in Indonesia. It is divided into three parts, West Java, Central Java, and East Java. Evidently, staying in one island "Java Island" does not guarantee that Javanese people have same conceptual meaning about Indonesian popular food. This study discovers, there are several popular foods which have different food concept in each area. It is caused the food is beyond the expectation. This study categorizes the finding into two parts as below.

\section{Having same food name but having different food concept}

The several Indonesian popular foods for this first category are mentioned as below.

\section{A. Bakso or Baso}

This dish is well known among Indonesian people. Children to adult like eating bakso. It is easily found from peddler, pushcart man to restaurant. If buyer buys a portion of bakso, the seller will give a bowl of meatballs commonly. Meat ball is made of a mixture of beef, fish or chicken and tapioca flour which are grinded. The composition of the meat depends on the seller. 
Then, it is formed in round. Besides, the seller also adds bihun (angel hair or kind of noodles), noodle, piece of cabbage, and beef broth. The tomato sauce, chili sauce, and ketchup can be mixed directly in the bowl or separately in other place (small bowl). It is based on the buyer's request.

Unfortunately not all buyers will get their order like previous description. In Surabaya, buyer will get not only meat ball but also tofu, siomay (dumpling), and gorengan (fried dumpling). The buyer can choose the item by itself, such as a bowl of full meat balls or mixed all items, or the combination of meatballs, tofu, and dumpling. It is up to the buyer's willing.

There are two types of tofu, steamed tofu or fried tofu. Both of them are filled with tapioca flour or beef or the mixture of both. Dumpling has two types as well. The filling is the same as the tofu. The different is covered by cabbage or dumpling skin. For gorengan is filled with vegetable or beef or vegetable and tapioca flour. It is interpretation of bakso in Surabaya and Sidoarjo. In Malang it is almost the same, but it has lettuce for the vegetable. It replaces the piece of cabbage.

In other hand, the bakso is not same in Kudus and Ponorogo. When Surabaya people take vacation and order bakso in Kudus or Ponorogo, they will get bakso which is not same as in Surabaya. People who like tofu, dumpling, or gorengan will not get them in Kudus and they will not either in Ponorogo. The buyer will only get a bowl of meatball in Ponorogo. The vegetable and the broth are same. It is quite different in Kudus. The word bakso in Kudus is out of Surabaya citizen's expectation. Commonly bakso refers to beef meatball, but in Kudus there is Kudus buffalo bakso. The meat is from buffalo meat. The vegetable is similar; and there is no tofu and dumpling. If the buyer requests gorengan, the seller will add gorengan pangsit (fried dumpling without filling, in small shape likes cracker) which is out of their expectation. That is a little bit surprising, becausegorenganpangsitisusually used as crackerinmiepangsit(type ofnoodles dish).

According to a few respondents who were born and grew up in Kudus, the reason why several people use buffalo meat nowadays is due to religion issue in the past. Kudus is a famous city in Indonesia, especially for Moslem people. There are two Islamic places that can be visited by pilgrimages. Indonesian people called it as Sunan Kudus and Sunan Muria. They are a place where the tomb of Sunan Kudus and Sunan Muria located. They are scholars who introduced Kudus citizen with Islam in the past.

The history records that those two scholars are included WaliSongo. It is a term for nine scholars who had dedicated their life to expand Islam in Java Island. Before Sunan Kudus introduced Islam, most of Kudus citizens were Hinduism. To keep tolerance to Hinduism, Sunan Kudus used the personal approach. In Eid Adha he asked the followers of Islam at that time to slaughter buffalo instead of cow. As we know that cow is holy animal for Hinduism. In other hand, Moslems commonly slaughter cow, sheep and or goat in Eid Adha in Indonesia. How Moslems slaughtered a cow which is a sacred animal for the Hindu resident in that place. Then, Sunan Kudus slaughtered buffalo to respect the Hindu resident. Moreover, Islam allows the Moslem to replace cow with buffalo. It was a way of Sunan Kudus to teach religious tolerance for Kudus citizens without breaking out Islamic rule. In present Kudus citizens keep slaughtering buffalo instead of cow. It is still happened when it is in Eid Adha too. It is to keep tolerance and respect for existed Hindu people there and 
to keep Sunan Kudus' teachings. Furthermore, a quantity number of buffalos are more than cow, for there are breeder who raise buffalo. The meat of buffalo is also traded in the market. It causes meat of buffalo becomes common in Kudus and Kudus buffalo bakso does too automatically. Actually there is bakso which is made of beef in Kudus, but the famous one is with buffalo meat. It will be different in Surabaya. There is no meat of buffalo. The sellers commonly sell meat of chicken, goat, fish or beef. Therefore, bakso in Surabaya refers to meat ball which generally is made of beef as main ingredient and mixed with chicken, fish, or full of beef.

Actually Kudus people use buffalo meat not only in bakso but also in other dish such as soto and sate. Because bakso becomes favorite food in Indonesia community, Kudus people make it by using buffalo meat as their habit which is passed down from their ancestors. If the dish which uses buffalo meat has delicious taste, the people will cook it again. So, not all dishes can use buffalo meat. It depends on the taste of the dish.

Few other respondents stated that actually bakso comes from China. One of respondents stated that China dish generally uses bak- for the food name like bakpao and bakmi. Bakindicates pork. Chinese people can eat pork, but it is different in Indonesia. Most of Indonesian citizens are Moslem who are not allowed to eat pork. They adapt the food by changing the pork with using authorized meat based on Islam to enjoy the food. Consequently, bakso with beef has become famous food in Indonesia right now. In this case they represent the culture unconsciously through the belief and the way they choose the food ingredient.

\section{B. Sate or Satay}

Sate is a seasoned dish, skewered and grilled meat on charcoal fire. It is served with rice or lontong (rice cake) and peanut sauce. The meat is chopped in diced or sliced. The skewers are from the coconut palm frond, but it often uses bamboo skewers. Although sate is kind of popular food in Indonesia, each area has different own version of it.

In Surabaya, Sidoarjo, and Ponorogo people like eating sate with peanut sauce. The different is, Ponorogo people do not mix much ketchup directly; and the taste is spicier. The colour of peanut sauce is light brown. People who like sweet thing can add ketchup in the sauce when they eat it. Whereas people in Surabaya and Sidoarjo mix the ketchup to the sauce directly. It makes the sauce color to be dark brown. The seller does not add chili to the sate sauce without the buyer's request. The buyers who like spicy can request to add chili directly into the peanut sauce or add by themselves when they eat it. The similarity is the meat. It is grilled meat of chicken or goat. The peanut sauce is made of peanut, chili, garlic, and little salt.

In other city, the sauce is only ketchup, onion, and sliced chili. It is without peanut. That place is in Kudus. Sate Kudus uses meat of buffalo as main ingredient. Buffalo meat is easy to be found in traditional market in Kudus. As the previous explanation, the taste must be different likewise. Yummy or not, it depends on the eater. Everyone has own standard taste.

In present, not only meat but also fruit are made like sate concept. The presenting looks like sate. Instead of grilling, the fruits are dipped into melted chocolate. The skewered fruit is for the dessert; and the grilled meat is for main course.

1. C. Soto 
Soto is composed of broth, vegetable, and meat. It is served with rice. Even though people can find it in cities of Indonesia, the concept of this dish is various. Several cities (the example is in Surabaya, Sidoarjo, Gresik, and Lamongan) serve the soto with adding cabbage and or bean sprout as the vegetable and adding beef or meat of chicken in broth. The colour of the broth is yellow due to turmeric. The sellers usually add koya (prawn crackers which is made of prawn crushed and mixed with crushed fried garlic). By adding koya, the taste is more seasoning.

In Kudus, the soto uses the meat of buffalo because of local consumption of meat. The broth is more solid due to coconut milk and without adding koya. It is rarely to find soto with clear broth (yellow broth due to turmeric like in Surabaya) and with meat of chicken. Most of Kudus citizens make soto with broth of coconut milk.

1. D. Rawon

This dish has strong taste of beef black soup. The black soup is from keluak or black nuts. It is served with rice, prawn crackers and sprinkled a little bean sprouts. It is quite easy to be found in Surabaya and Sidoarjo, but it is hardly to be found in Kudus and Solo. Even if there are sellers who sell rawon, it can be confirmed that the sellers come from outside Kudus and Solo. It is caused the presenting of rawon in black soup. The Kudus citizens seem to like clearer or brighter color broth than black broth.

\section{Having different food name but having similar food concept}

People are sometimes confused when they do trading activity in other cities, especially in dish case. When buyers just order the same food which is as same as in their hometown (without realizing it has different name in other cities), the sellers will get difficulty to understand until the buyers point the food. Firstly, the seller will say "I don't have". In fact the seller has it. It is happened too when speaker says a word which the listener never hears the word before. The listener will think the new word related to a name of new food. When the speaker shows the food or describes it, the listener will get the speaker's point and explain that the name is different in listener's area. This study has already found several foods for this case as below.

\section{A. Ote Ote or Bakwan Sayur or Heci or Pia-pia}

It is a type of fried foods which made of flour mixed with some vegetables (carrot, cabbage, bean sprout, celery, and leek leaves) and sometimes with shrimp. The fried food is often eaten with sambal petis (dark shrimp paste sambal) or chili. It is not hard to make it. People just need a little patience and precision to print it using a ladle. Because of using ladle, the shape becomes flat round shape. In Surabaya and sidoarjo, this dish is called ote-ote. People name it as bakwan sayur in Solo and Kudus; heci or pia-pia in Ponorogo.

\section{B. Tempe Tepung or Mendoan or Gimbal Tempe}

The main item of this dish is tempe. At glance this dish looks like tempe in covered by flour. In fact, it has additional ingredients, such as leek, salt, turmeric or coriander. Each area has own version of this dish. The similarity is the tempe is dipped into flour and fried. It is called tempe tepung (floured tempe) in Surabaya, Sidoarjo; mendoan in Solo, Jogja, and Kudus; gimbal tempe in Gresik. It is served with chili or ketchup sambal. It is usually eaten as side dish or complementary foodofsayurasem(tamarindvegetablesoup)orsayurbening(clearsoup)in Surabayaand Sidoarjo. 


\section{C. Gimbal Jagung or Dadar Jagung or Bakwan Jagung}

Corn is main item for this dish. The other ingredients are egg, chili, garlic, salt and onion. Egg is used to bind the corns. People name it gimbal jagung in Gresik; dadar jagung in Surabaya, Sidoarjo; bakwanjagung in Ponorogo, Kudus. People usually eat it as complementary food as well.

Ote-ote, Mendoan, and Dadar Jagung are belong to fried food, because the way to cook it with frying the food. Those food are not main course. People in every place in Java eat them as snack or as complementary food. People can find them in food stalls easily. In kudus they are commonly eaten as snack while waiting the main course ready or while chatting with friends. In Sidoarjo, Surabaya, and Gresik it is also the same for oteote, whereas mendoan, and dadar Jagung are common eaten as complementary food.

People can make those famous food at home. Nonetheless, not all of them can be served as daily menu at home. This study analyses that it is only soto, rawon, mendoan, and dadar jagung are generally cooked as daily menu. They prefer cooking simple dish for daily menu. They often cook sate, bakso, and ote-ote at home, because it takes time to cook them. People would prefer to buy outside rather than to make them at home.

In other hand, Javanese people usually serve soto, bakso, rawon, or sate for special event such as in wedding party or regular social gathering. Those dish are belong to main course. The main ingredient of the food is meat. People usually choose the meat based on their financial capabilities and meat prices. For example is in Kudus, if they can afford to buy buffalo meat for soto, they will use it for the dish. If they cannot afford to buy buffalo meat, they will use meat of chicken. But it depends on people who get the event. In this case, everyone can eat no matter what social class they have. The taste of food in Central Java is mainly sweeter than in East Java. Eastern Javanese people like spicy food and seasoned food.

Surabaya, Sidoarjo, Gresik, and Ponorogo are in East Java. Solo, Yogya, and Kudus are in Central Java. Even living in the same island cannot be guarantee that there will not be the different conceptual meaning in referring Indonesian Popular Food. No wonder people sometimes misunderstand or get wrong perception to refer the food when they travel in other cities. It is caused the food is not same as in their own city despite having same food name. The other cities have own food concept. It means that each city has own conceptual meaning of food. The conceptual meaning is from people perception. When there is distinctive perception between two people, it means person's perspective on its mind is different with other. It will be clear if the perception is matched with the object. It is happened because there is culture behind it which is from their ancestors. Then it becomes habit. Group of people repeat their cooking way many times with same concept. It is continued by next generation. Therefore, it becomes their cooking habit and their dish characteristic. It is the way they create their culture about food.

This study finds culture through the conceptual meaning of Indonesian popular food above. People who live in East Java and Central Java have different culture, such as in food taste, type of food (main course, snack, or complementary food), and using various ingredient. The example is bakso, soto, and sate in Kudus. Buffalo meat is used because of religion issue in the past which affects the life style in food. Furthermore, this study discovers that East Java 
and Central Java have also same culture, such as the use of food for special event (wedding party or regular social gathering) and the eater (everyone can eat, there is no social class).

\section{CONCLUSION}

Language and culture are related to each other. The language has a function as a communication tool, and the culture is the outcome of language users. The geography position of each area affects the use of language and culture automatically.

This study discovers culture in particular area or place through distinctive conceptual meaning. First, it is from people's perspective. Then, it will be matched with the food. The perspective comes from people experience or habit. Indonesian popular food in East Java has different conceptual meaning from Central Java. This study categorizes in two types, having same food name but having different food concept and vice versa.

There is culture which is behind the conceptual meaning of food which is passed down by each ancestor in each area; and it is preserved by next generation. The different culture between East Java and Central Java are the taste of food, type of food, and the use of various ingredients. At the same time, the similar culture that East Java and Central Java have is the use of food for special event and the eater (all people can eat it).

\section{REFERENCES}

Crystal, David. (2008). A Dictionary Of Linguistics And Phonetics Sixth Edition. UK: Blackwell Publishing.

Fromkin, Victoria. Rodman, Robert. Hyams, Nina. (2011). An Introduction to Language 9th edition. US:Wadsworth Cengage Learning.

Leech, Geoffrey. (1981). The Study of Meaning: Second Edition. England: nd Penguin Books Ltd. Meyer, Charles F. (2009). Introducing English Linguistics. UK: Cambridge University Press.

Pateda, Mansoer, Dr. (1990). Linguistik (Sebuah Pengantar). Bandung: Angkasa.

Yule, George. (2006). The Study of Language Third Edition. UK: Cambridge University Press. 